\title{
The Rules and Practice of the Investiture VOTE IN THE CZECH REPUBLIC ${ }^{1}$
}

\section{Robert Zbíral ${ }^{\star}$}

\section{Faculty of Law, Palacký University Olomouc, Czech Republic email: robert.zbiral@upol.cz}

ZBÍRAL, Robert. The Rules and Practice of the Investiture Vote in the Czech Republic. International and Comparative Law Review, 2011, Vol. 11, No. 2, pp. 43-62. DOI: 10.1515/iclr-2016-0103.

\begin{abstract}
Text analyzes in detail legal situation dealing with the Czech government investiture vote. Constitutional foundations are tested against political practice, which is often quite different. The Results confirms the construction of investiture vote is less important that notorious weakness of the government majority in the Chamber of Deputies.
\end{abstract}

Keywords: investiture vote, Czech government, political practice, Czech Chamber of Deputies

\section{Introduction}

The Czech Republic, established in 1993 as one of the successors of the former Czechoslovakia, is a relatively young state. It of course also belongs to the group of post-communist countries, which had been under the dominance of communist party for 40 years, which prohibited any development of democratic instruments. On the other hand, unlike many other Central and Eastern European (CEE) states, it could have built on the experience with regime between World Wars, which was praised by numerous at that time (but contemporary as well!) experts as one of the most modern democratic political systems in Europe. The positive example of the First Republic (1918-1938), together with the relatively advanced economy, were probably the main reasons that contributed to the successful transformation of the Czech Republic to a democratic state with a market economy. Surely there have been numerous glitches and drawbacks on

\footnotetext{
Head of Department of Political and Social Sciences, Faculty of Law, Palacký University Olomouc, Czech Republic

1 The first version of this text was presented at the ECPR General Conference in Reykjavik (August 2011). Author would like to thank discussant Torbjörn Bergman and other participants in the panel for their valuable comments, all mistakes remain his own. The financial support of Palacký University in Olomouc (Internal Grant for 2011) and Czech Ministry of Education (National Plan of Research II: 2D06016) is greatly acknowledged.
}

\section{๑) Palacký University Olomouc, Czech Republic, 2011. ISSN 1213-8770 (print), ISSN: 2464-6601 (online).}


the way, but generally speaking the journey was more straightforward than in the other countries of Central (not to say Eastern) Europe. ${ }^{2}$

From a political viewpoint the Czech Republic is a very interesting case. It is a unitary state with a classic parliamentary political system. The legislative power is represented by bicameral parliament. While both chambers are selected by direct vote, the lower chamber (Chamber of Deputies) serves as the real powerhouse, the upper one (Senate) has only a moderating function. ${ }^{3}$ Asymmetry between chambers is confirmed by the legislature-executive relations, as the Constitution proclaims that government is responsible only to the Chamber of Deputies. The President is selected indirectly by the Parliament, but at the same time his role is far from ceremonial (see below). The Chamber of Deputies is elected by a proportional system with modified $\mathrm{D}^{\prime}$ Hondt formula, the threshold is set to $5 \%{ }^{4}$

While there is nothing exceptional in this outline, the practical functioning of the system is unusual. With a pinch of salt, we could describe it as simultaneously highly stable and unstable. The first pattern is represented by the main actors. First, so far the Czech Republic had only two presidents: Václav Havel (19932003) and Václav Klaus (since 2003), their position has been even stronger than the Constitution would suggest. Among the political parties, the left-wing social democrats (ČSSD) and right-wing civic democrats (ODS) have consistently been by far the strongest political parties, followed by communists (KSČM) and several smaller centre-right parties (eg. Christian democrats - KDÚ-ČSL). Here comes the instability factor. Due to the proportional system, no party was ever been able to gain an absolute majority of votes, which means coalitions need to be formed. ODS and ČSSD are fierce ideological rivals and although there were moments when big coalitions were considered, it never (openly) happened. In light of this and the fact that KSČM is intentionally left out of any coalition negotiations by both main parties, the possible win set for majoritarian government is indeed quite small and in reality could be reached only with the aid of those few centre-right parties that side either with ČSSD (2002-2006) or ODS (1993-1998, 2006-2009, since 2010). The winning coalition has usually been able to hold a miniscule majority in the Chamber of Deputies, sometimes only with the help of deputies that changed their allegiance (so called "přeběhlík" / crossrunner ).

2 For the general outline of transformation process in English, see MACHONIN, Pavel. Modernisation and Social Transformation in the Czech Republic. Czech Sociological Review, 1996, vol. 4, no. 2, pp. 171-186.

3 Due to the low competences of the Senate, its composition has never been a factor during formation of the government, even in case of the minority one, so the hypothesis of Druckman et al. is not confirmed in the Czech case (DRUCKMAN, James et al. Influence without Confidence: Upper Chambers and Government Formation. Legislative Studies Quarterly, 2005, vol. 30, no. 4, pp. 529-548).

4 Outline of Czech political system is provided by CABADA, Ladislav, VODIČKA, Karel. Politickýsystem České republiky [The Political System of the Czech Republic]. Praha: Portál, 2007. 
The vote of investiture is without doubts an important part of the government formation process in many countries, while at the same time the amount of literature devoted to the topic is quite negligible. The ambition of the presented article is to provide an empirical case study of the process and impact of the investiture vote in the Czech Republic. At first sight, single case-studies are less useful than comparative papers covering many countries. On the other hand, the rules of the investiture vote and their application are so diverse that any comparison is naturally but a schematic one, in this case a detailed discussion of one country's experience might be valuable as well. The vote of investiture in the Czech Republic follows a positive parliamentarism pattern. ${ }^{5}$ Given the background sketched in the previous paragraph, the Czech Republic underwent a wide variety of situations including minority and caretaker governments. In order to form a government, the politicians were forced to "invent" numerous innovative instruments that modified or broadened the constitutional rules. Description of these mechanisms and analysis of their efficiency might shed some light not only on the Czech situation, but also serve as a comparative basis for other states' practice or possible amendment of their own rules. The article deals only with the obligatory vote of investiture faced by new governments, not the voluntary ones (vote of confidence) the ruling governments sometimes decide to endure for various reasons. ${ }^{6}$

Apart from the introduction, this article is divided into four parts. The second chapter describes the formal rules dealing with the process of government formation both in Constitutional and ordinary laws, including several problematic black spots in the Czech legal order. The subsequent part forms the core of the text and analyses practical experience with government formation with the emphasis on the vote of investiture. It is divided into three subsections; the first concentrates on the preliminary phase characterized by the importance of the President, then there is an interim explanation how the Czech governments were able to obtain support in practice and finally I move onto the closing phase in the Chamber of Deputies. As some political parties or experts were dissatisfied with the functioning of the present system, various reforms were offered, these are discussed in part four. The Conclusion assesses the Czech experience and tries to ascertain if the vote of investiture forms a deciding factor in the Czech political system, finally a short comparison is made to the situation in other states.

5 BERGMAN,Torbjörn. Formation rules and minority governments. European Journal of Political Research, 1993, vol. 23, no. 1, pp. 55-66.

6 Usually in order to show unity to the opposition or public. There have been so far only two such votes since 1993 in the Czech Republic $(1997,2003)$. Third possibility is a vote of noconfidence initiated by the opposition, there have been about twenty attempts made, only one of them successful (2009). 


\section{Constitutional framework}

The formal process of government formation in the Czech Republic is relatively straightforward; the necessary rules are given in Art. 68 of the Constitution (see below). As I already said, it is a clear example of positively formulated formation rules, if we use a more detailed classification of Lieven De Winter, than it belongs to the group of "weakest positive", because a simple majority is sufficient to gain confidence. When I pointed out the importance of the First Republic legacy for the Czech Constitution, it is worthy to note that in this case the tradition was breached. The Constitution from 1920 prescribed the negative formation rules, ${ }^{8}$ which was exploited for the formation of non-political governments. ${ }^{9}$ The investiture vote was introduced by the first Communist constitution from $1948,{ }^{10}$ the constitution from 1960 dismissed any notion of the division of powers and established the dominance of the National Assembly, so the duty for the government to undergo investiture vote was implicitly still there. ${ }^{11}$ Of course, it was the Communist Party that held all the power and therefore practically it hardly mattered. After the Velvet Revolution in 1989 numerous parts of the 1960 Constitution were changed, but the vote of investiture procedure remained. During the drafting of the Constitution of the new Czech Republic, there was no real discussion on the issue, return to negative rule of the First Republic was probably rejected on the basis of the mentioned undesirable effects which lead to periods of instability. ${ }^{12}$ The subsequent part describes and analyses the outline of the process.

\section{Article $68^{13}$}

1. The Government shall be accountable to the Chamber of Deputies.

2. The Prime Minister shall be appointed by the President of the Republic who shall appoint on the Prime Minister's proposal the other members of the Government and shall entrust them with the direction of individual ministries or other agencies.

7 DE WINTER, Lieven. The Role of Parliament in Government Formation and Resignation. IN: DÖRING, Herbet (ed). Parliaments and Majority Rule in Western Europe. Frankfurt: Campus Verlag, 1995, p. 135.

8 See Art. 70-78 of Act no. 121/1920 Coll.

9 For the government formation experience of the First Republic see BROKLOVÁ, Eva. Československá demokracie: politický systém ČSR 1918-1938 [Czechoslovak Democracy: Political System of Czechoslovak Republic 1918-1938]. Praha : Sociologické nakladatelství, 1992.

10 Art. 82 of Act no. 150/1948 Coll.

11 Compare Art. 44 para 1 of Act no. 100/1960 Coll.

12 The explanatory memorandum to the Constitution is of little help here, because it is actually much shorter than the Constitution itself. See Print 152, Czech National Council (1992-1992). Availaible at http://psp.cz/eknih/1992cnr/tisky/index02.htm (visited on 14th July 2011).

13 Act no. 1/1993 Coll. Translation from http://www.senat.cz/informace/zadosti/ustava-eng. php (visited on 14th July 2011). 
3. Within thirty days after its appointment the Government shall present itself to the Chamber of Deputies and shall ask it for a vote of confidence.

4. If a newly appointed Government fails to win the confidence of the Chamber of Deputies, the procedure specified in paragraphs 2 and 3 shall be followed. If a thus appointed Government again fails to win the confidence of the Chamber of Deputies, the President of the Republic shall appoint a Prime Minister on the proposal of the Chairman of the Chamber of Deputies.

5. In other cases the President of the Republic shall appoint and recall on the proposal of the Prime Minister the other members of the Government and shall entrust them with the direction of ministries or other agencies.

Art. 68 para 2 to 4 is applicable to all government formations, both after the general elections or in case the actual government resigns. The first step is entrusted to the President, who appoints the Prime Minister (PM). It is her of his autonomous decision not dependent on any proposal, he ${ }^{14}$ does not need a co-signature from the government. ${ }^{15}$ The President's free hand is strengthened by the fact that he is constitutionally irresponsible and there are no time limits set for the selection. Indeed, the only legal limits of his behaviour are rather a vague proclamation in the President's oath, ${ }^{16}$ he must also respect the pluralism of political parties (see Art. 5 Const.). In light of this, the decision is not entirely arbitrary, ${ }^{17}$ not to speak about the political dimension of the question (see further).

After the appointment the PM (in waiting) forms his government, now it is him who is not restrained by any rules, indeed the text of the Constitution does not (nor any other laws) put any limit on the number of ministers or their qualification, apart from the obvious ones. ${ }^{18}$ The role of President in the appointment of ministers is hotly debated. The strictest interpretation claims he is bound by the proposal of the PM and simply confirms his decision, ${ }^{19}$ according to the intermediate version he could only review legal issues such as incompatibility of

14 As Czech politics is (unfortunately) predominantly male environment, I will use only „he“ or "his" throughout the text.

15 Czech Constitution divides the President's competences into two groups: those that need to be confirmed by the signature of the PM (see Art. 63 para 1 Const.) and those that are his "own" (see Art. 62 Const.). In this case even practically it would hardly be logical to require PM's signature (the leaving one? the newly appointed one?).

16 „...I shall perform my office in the interest of all the people..." (Art. 59 para 2 Const.).

17 Similarly MIKULE, Vladimír. k čl. 68 [Commentary to Art. 68]. IN: SLÁDEČEK, Vladimír et al (ed). Ustava České republiky: Komentár [Constitution of the Czech Republic: Commentary]. Praha: C.H. Beck, 2007, pp. 505-506.

18 Eg. age and sanity (see Art. 70 Const.). For example strangely there is no requirement for Czech citizenship, and there was already a minister with only German citizenship.

19 For example PAVLÍČEK, Václav, HŔEBEJK, Jiří. Ústava a ústavní rád České republiky. 1 díl: Ústavní systém [Constitution and Constitutional Order of the Czech Republic. $1^{\text {st }}$ part: Constitutional System].Praha: Linde, 1998, p. 249. 
functions ${ }^{20}$ the last group supports wide discretion of the President, who could reject any proposal for whatever reason, including the personal or political dislike of the nominated minister. ${ }^{21}$ I personally tend to agree with the second view, but the whole issue remains so far mainly theoretical as the PM did not propose anybody too controversial. What is more important is the timeframe of the appointment process. Although the Constitution does not prohibit the appointment of the PM and his government in one moment, a two step procedure is more likely. This enforces the PM by giving him time space to negotiate his team and prepare for the showdown in the Chamber of Deputies. The question is for how long this space should be. Theoretically it is unlimited and the PM could even artificially prolong it when the bulk of government is already formed, ${ }^{22}$ on the other hand he is at this point not a proper PM, the actual executive powers are still held by the previous (leaving) government. The Czech Constitution thus does not preclude a period with two legitimate PMs, no matter how undesirable this state of affairs is.

By the official appointment of the government starts the 30 day deadline, during which the government has to ask for the vote of investiture. However the situation is more complicated after elections than the Constitution would suggest. According to the Chamber of Deputies Rules of Procedure (RP), the first session after elections is so called the "founding" one with a fixed programme such as the selection of its own leadership or committees. ${ }^{23}$ The vote of investiture could be placed on the agenda of regular session only, which might not start sooner than the founding one is closed. It is therefore not inconceivable that the government will be appointed during the founding session, but it would be a risky step because the deadline could run out in vain. ${ }^{24}$

If the government is rightly appointed (and the founding session concluded), the chairman of the Chamber of Deputies has a duty to place the vote of investiture on the agenda in order to meet the 30 days deadline (Art. 82 para 2 RP). As

20 For example ŠIMÍČEK, Vojtěch. Ústavněprávní pravidla sestavování vlády po volbách a jeho praxe [Constitutional rules of government formation after elections and its practice]. IN: LINEK, Lukáš (ed). Volby do Poslanecké sněmovny 2002 [Elections to Chamber of Deputies 2002]. Praha: Sociologický ústav, 2003, p. 167.

21 Eg. Václav Klaus' legal adviser (HASENKOPF, Pavel. Bytí a nebytí českých vlád, tentokrát podle české ústavy [Existence or nonexistence of Czech governments, this time according to Czech Constitution]. 31th August 2006. Available from http://sumavak.bloguje. cz/386844-topolanek-uz-zase-sestavuje-vladu.php (visited on 14th July 2011)).

22 One of the Czech Acts (No. 2/1969 Coll.) contains a list of obligatory ministries, the term „appointment of government" indicates there must be the whole government, so the PM might not for example nominate the minister of finance and the whole process is blocked.

23 See Art. 22-28 of Act no. 90/1995 Coll. English (but not the latest) version available at http://www.legislationline.org/download/action/download/id/2058/file/Czech_Rules_ Procedure_Chamber_Deputies_1995am2006htm/preview (visited on 14th July 2011).

24 For details SYLLOVÂ, Jindřiška, KOLÁŘ, Petr. K ústavní úpravě jmenování vlády [On the Constitutional Aspects of Government Appointment]. Study 1/174 of Parliamentary Institute, 2006, pp. 6-9. 
was already said, a simple majority of the present deputies suffices. Because the lowest quorum is set to one third of the full house which consists of 200 deputies (Art. 70 para $1 \mathrm{RP}$ ), theoretically the government could win the investiture with the active support of only 34 deputies. If the government survives the investiture vote, it gained confidence and might proceed to perform its task as a "fully legitimate" executive.

Art. 68 para 4 Const. deals with situation when the appointed government fails to win the investiture vote. Firstly it must resign (Art. 73 para 2 Const.), if the government hesitates, the President will dismiss it himself (Art. 75 Const.). Then the whole process described above is repeated with the hope that the President will be more luck in his second choice and the Chamber of Deputies will be more conciliatory. If the expectations are not fulfilled, the third PM is again appointed by the President, but this time on the proposal from the chairman of the Chamber of Deputies. ${ }^{25}$ The logic of this solution is based on the assumption that the chairman should be more knowledgeable with the situation in the Chamber of Deputies than the President and his choice will have more chances to succeed. I find numerous objections against this reasoning, namely that the chairman's decision is based simply on his personal wishes and therefore does not have to be based on the opinion of the Chamber's majority. If even the third attempt fails the President has a right to dissolve the Chamber of Deputies (Art. 35 para 1 let. a) Const.), which might serve as a motivation to deputies to act more "positively". The Constitution does not foresee a situation in which the Chamber is not dissolved in this case, I guess a logical interpretation indicates there will be a new third attempt by the chairman of the Chamber of Deputies.

A more detailed analysis of the abovementioned procedure will reveal many loose ends, but these are rather pet objects of hardcore constitutional jurists and therefore out of article's reach. Still there are two open issues that require closer inspection. The first of them is the problem of what would happen if the appointed government misses the 30 days deadline and will not ask for the vote of investiture. The Constitution does not anticipate it and the situation is not specifically mentioned as a reason for obligatory government resignation in Art. 73 para 2 Const. ${ }^{26}$ Some experts ${ }^{27}$ infer from the text's silence that actually there are negative rules of government formation in the Czech Republic and the appointed government may fully perform its duties unless the Chamber of Deputies forces it to resign by a vote of no-confidence. ${ }^{28}$ It must be said such views are in absolute minority and despite the fact that the deadline is only formal, all noticeable lawyers in the Czech Republic argue that failure to ask for investiture represents

25 This mechanism is somewhat similar to standard procedure in Sweden.

26 Therefore the President is also not entitled to dismiss the government.

27 Eg. BÁRTA, Jan. Prezident republiky a jeho pravomoci v ústavním systému [President of the Republic and his Competences in the Constitutional System]. Právník, 2007, vol. 146, no. 2 , pp. $140-145$.

28 Which requires absolute majority of votes in the Chamber (at least 101), see Art. 72 para 2 Const. 
a grave constitutional offence which was simply out of the Constitution's drafters imagination. ${ }^{29}$

The last point requiring discussion is the issue when exactly the government has to undergo the vote of investiture. Clearly it concerns the governments after elections and the successors of governments forced to resign after the vote of no-confidence. But what about other cases, such as major reconstruction of the government? Although the Constitution lacks any leads, the question revolves around the position of the PM. One group of scholars argue he is the central element of any government, if he resigns, a new government must be appointed and ask for the investiture vote. Reversely, if the PM remains in office he is able to replace even all ministers or change the parties in the coalition. This position is based on the notion that there could hardly exist a government without its head and on the interpretation of Art. 68 Const., which seems not to allow the appointment of a new PM by other means than those described above. ${ }^{30}$ Opponents claim total dependence of government on the PM is inconvenient and unfair, what if he simply dies or resigns because of his personal failure? Is it not sufficient then to simply appoint a new PM rather than undergo the cumbersome process of old government resignation and new government formation? Theoretically this opinion is based on the notion that the Czech government is a collective body (see Art. 76 para 1 Const.) and the $\mathrm{PM}$ is only primus inter partes, there is no tradition of a Chancellor system as in Germany. ${ }^{31}$ Practice has tended to develop towards the first position.

\section{Vote of investiture in practice ${ }^{32}$}

The first Czech government came to office on $1^{\text {st }}$ January 1993. The Constitution directly declared (Art. 108) that it did not have to undergo the regular appointment process, because it was the successor of the government of the Czech Republic (as part of Czechoslovakia), appointed after the general elections in 1992. Because this government ruled for the rest of the full election period, it was not until after the 1996 elections the first government formation process took place. Since then, ten governments have undergone thevote of investiture, five of them following new elections. Out of the ten, there were three minority governments and two caretaker (half-political) ones, so we have quite a varied

29 But see former PM Topolánek's creativity below.

30 See PAVLÍČEK, Václav et al. Ústavní právo a státověda II [Constitutional Law and State’s Law]. Praha: Linde, 2001, p. 358, also FILIP, Jan. Vybrané kapitoly ke studiu ústavního prá$v a$ [Selected Chapters to the Study of Constitutional Law]. Brno: Masarykova univerzita, 2001, p. 324.

31 See MOLEK, Pavel. Komentář k čl. 74 [Commentary to Art. 74]. IN: BAHÝL'OVÁ, Lenka et al (eds). Ústava České republiky: Komentár [Constitution of the Czech Republic: Commentary]. Praha: Linde, 2010, p. 870; ŠIMÍČEK 2002, p. 166.

32 Information in the article is also based on dozens of articles published in various newspapers (Mladá Fronta, Lidové Noviny, Právo, Hospodářské noviny) between 1996 and 2010. They are available on request from the author. 
sample (see table in the annex). Surely there are certain differences between formations of each type of government, but as I want to point out only the interesting points, all instances will be tended together, with the emphasis on the post-election process.

\subsection{Introductory phase: Role of the President}

Czech politics has little experience with pre-election coalitions or presentations of promises with whom each party wants to govern. Politicians aim to increase their share against all competitors; even those ideologically close, and always justify their silence by saying that "only the voter will decide how the next government will look". Conversely, they rather stress with whom they will never form a government, often the mutual incompatibility among parties is so complex it would seem there is mathematically no chance for any government, barring the unlikely gain of majority for one party. In light of this and numerous previous breaches of such "never" vows "forced" by electoral results, nobody takes them seriously.

The informal negotiations among parties typically start the minute the first predictions of results are made public. In 2006 or 2010, ODS together with smaller center-right parties very swiftly announced agreement on future cooperation in government, but the first official move must be made by the President. As was emphasized above, so far the Czech Republic has experienced only two persons in this office. Both Havel and Klaus had a very strong position and acted actively during the negotiations. The major difference between them was their political affiliation - while Havel was traditionally non-partisan, Klaus used to be a long-term chairman of ODS. On the other hand, he did not like his successor Mirek Topolánek, therefore there was hardly any positive bias towards this party. AnOther important factor in Klaus's behaviour proceeded from his previous experience: when Klaus's second government was forced to resign in 1997, he strongly criticized the course of action Havel chose and labelled his steps as activist, there were afterwards even efforts to constitutionally curb the President's powers (see below). When Klaus later acquired presidential office, he indicated he would have a more passive attitude in these situations.

Despite the opportunity to appoint whoever they want, both President's course of action was traditionally careful and reflected the electoral results. It means that in almost all cases it was the leader of the strongest party in the Chamber of Deputies who was the entrusted initiative. Several times he was not directly appointed, but asked (formally - see the table, or informally) to start the negotiations. The role of informateur is not constitutionally sanctioned and sometimes it is critized because it prolongs the whole procedure (there is no time limit) and strengthens the President, who is not risking forfeiting his first official nomination. ${ }^{33} \mathrm{He}$ could also lay conditions to the informateur, an activity

33 See eg. DOLEŽAL, Bohumil. Ústavní záruky našich politických krizí [Constitutional Guarantees of Our Political Crises]. 4th July 2004. Available from http://bohumildolezal. 
enjoyed heartily by Václav Klaus, who exploited unclear majorities in the Chamber of Deputies. In 2004 he conditioned the appointment of Stanislav Gross on deliverance of 101 signatures from deputies supporting his planned government. ${ }^{34}$ Such an obligation constitutionally does not make sense, because first it changes the required simple majority to absolute one, secondly the deputies have a free mandate and any signature does not bind them to vote accordingly. Still Gross complied. Similar conditions were laid on Mirek Topolánek in 2006, however this was further complicated by the added requirement that there should be no cross runners. ${ }^{35}$ As the Chamber was divided 100:100 and the opposition represented by ČSSD and KSČM, the only solution to Klaus's wish would be great coalition of ODS and ČSSD. In this case it was Klaus who relented. In spite of the mentioned doubtful practises, the informateur's phase is generally accepted and slowly has become a constitutional custom. ${ }^{36}$ Both presidents were usually heavily involved in the negotiations, asked informateurs for regular reporting on their progress, invited the leaders of political parties for conversations or even organized common meetings when deadlock was looming. At the same time they however pretended to be "above" the quarrels and did not comment on their personal attitudes. ${ }^{37}$

After the successful conclusion of informal negotiations by informateur , The President appoints the PM. One might think that The President has more room for manoeuvre during the formation of caretaker governments, which during the First Republic were basically selected solely by the head of state. But as the Constitution requires a similar vote of investiture for any government, even in these cases there must be an agreement of political parties and in the past they have informally made it known who were acceptable candidates for the caretaker PM. Apart from caretaker governments, the only exception to the "leader of the strongest party=appointed PM" rule was in 2010, when the post was entrusted to Petr Nečas as the chairman of the second most successful party (ODS). Although the previous custom was broken, it was no arbitrary behaviour from the President, because ODS had already negotiated support from two other parties and with a common majority of 118 deputies, there was no chance of success for any other configuration.

Only after the 2006 elections the President had to progress to the second round of the PM's appointment, because his first choice, Mirek Topolánek, was

lidovky.cz/texty/rs521.html (visited on 14th July 2011).

34 Originally Klaus indicated that a majority of 102-105 deputies will be needed.

35 Paradoxical request indeed as Klaus himself relied on crossrunners when he was PM between 1996 and 1997.

36 RYCHETSKÝ, Pavel. Soudní přezkum aktů prezidenta republiky [Judicial Review of the President's Acts]. IN: ŠIMÍČEK, Vojtěch (ed). Postavení prezidenta v ústavním system České republiky [The Position of the President in the Constitutional System of the Czech Republic]. Brno: Masarykova univerzita, 2008, p. 152.

37 The consequences of this attitude were sometimes perplexing, as the leaders of each political party argued with the support or promises of Presidents that were clearly contradictory. 
not able to gain enough support for his team in the vote of investiture. After prolonged negotiations, during which the leader of second strongest party (ČSSD) Jiř́ Paroubek demanded his turn, Klaus again opted for Topolánek. Although the Constitution does not directly proscribe such a step, the decision was considered controversial by many. The general viewpoint is that it would be logical and fair to give a chance to somebody else, ${ }^{38} \mathrm{~A}$ well-known constitutional lawyer from the First Republic even claimed President is not allowed to name a person that was forced to resign. ${ }^{39}$ Theoretically it sounds fool proof, practical politics however does not always follow the blueprint: at that point Topolánek was able to lure two deputies from ČSSD and therefore had the needed majority. On the other hand it does not mean the President's attitude did not have any impact, had Paroubek been given a nod, it is not unlikely he would be able to persuade somebody else from the other camp to gain the vote he required.

After the PM is appointed, the role of the President is diminishing. With the exception of Václav Klaus, who (with no impact) raised objections against nomination of Karel Schwarzenberg to the post of Foreign Minister, ${ }^{40}$ presidents left a free hand to the PMs in selection of ministers, the governments as a whole were duly appointed once the teams were complete. At the beginning Václav Havel came to the Chamber of Deputies before the vote of investiture, defended the governments appointed by him and asked the deputies to support them, but after 1998 he ceased to do that and Klaus has never considered it.

\subsection{Interim explanation: How to create a "majority" in the Czech Republic ${ }^{41}$}

The appointed government requires the support of the majority of deputies in order to overcome the vote of investiture. Given the usually complicated situation in the Chamber of Deputies, resulting from irreconcilability of some subjects and the balance between left-wing and right-wing political parties, it could be indeed very difficult to succeed. How were the politicians able to overcome the hurdle? I will provide a brief historical sketch first. Sometimes circumstances predestined the results. In 1996, the parties of ruling coalition received only 98 votes, but the remaining 102 votes were divided among ČSSD, KSČM and extreme right-wing Republicans. These parties were too diverse to form a coalition, and as the governing parties rejected to cooperate with anybody else, the only other option than minority government was new elections. ČSSD assessed its options and preferred to act as "constructive" opposition, which meant its deputies left the chamber during the vote of investiture. Later the balance shifted thanks the first occurrence of cross runners, still Klaus' government resigned prematurely because of internal disputes. The subsequent caretaker government

38 Eg MIKULE 2007, p. 509.

39 WEYR, František. Československé ústavní právo [Czechoslovakian Constitutional Law]. Praha: Melantrich, 1932, p. 216.

$40 \mathrm{He}$ argued Austrian origin of Schwarzenberg was not compatible with defending Czech national interests.

41 See also the annual country reports in European Journal of Political Research.

\footnotetext{
๑) Palacký University Olomouc, Czech Republic, 2011. ISSN 1213-8770 (print), ISSN: 2464-6601 (online).
} 
of Tošovský ruled for only few months and won the investiture vote on a promise of early elections.

Elections in 1996 were won by ČSSD, which proposed a coalition to centerright parties and even offered a post of PM to them. They rejected, and the coalition between those parties and ODS was impossible due to personal hatred caused by the government's downfall in 1997. Surprisingly, ODS and ČSSD were able to close the so called "Opposition agreement", according to its text ODS tolerated social democratic government and promised not to initiate or vote for a vote of no-confidence. In return they received the position of Chamber of Deputies chairman for Klaus and together both parties planned to adapt the Constitution (see below) and change the electoral system to the majoritarian formula. ${ }^{42}$ Despite grave minority, the government was able to rule quite successfully for the whole period. While many Czech intellectuals criticized the arrangement as a simple division of power that breached any democratic standards, ${ }^{43}$ foreign commentators evaluated it through more pragmatic lenses. $^{44}$

In 2002 ČSSD won again, this time the same center-right parties agreed to a coalition which mastered the slightest majority of 101 deputies. The coalition survived for the whole period, however internal problems in its biggest member party meant three PMs took office in four years and due to abovementioned practice, a new investiture vote had to be organized each time, although both the composition of the coalition and even the majority of ministers remained the same. There were deputies crossing allegiance on both sides, somehow the government always had the upper hand.

The most difficult situation was after the 2006 elections. Parties positioned on the right side of the spectrum immediately announced an agreement, but they had only 100 deputies. A deadlock loomed, politicians were even not able to agree on the establishment of the Chamber's leadership, partly because any concession would be taken as a gesture of weakness, secondly because of the role the chairman plays during third attempt to appoint the PM. As was also explained, if the founding session is not finished, no appointment of new government could take place. In the end a low-figure deputy from ČSSD was elected as chairman based on a public promise he would step down before he had a chance to nominate the PM. Still this did not solve the governments' conundrum. Finally Klaus appointed Topolánek, but he still commanded only 100 votes. Therefore his advisers invented an interpretation that a tie during the vote of investiture is actually sufficient, but this crazy theory was rejected even by some of the ODS deputies. Finally Topolánek gambled and formed an ODS minority government

42 Electoral Act changes were annuled by the Constitutional Court for their unconstitutionality.

43 For typical example see TABERY, Erik. Vládneme, nerušit [We rule, do not disturb]. Praha: Respekt Publishing, 2008.

44 See ROBERTS, Andrew. Demythologising the Czech Opposition Agreement. Europe-Asia Studies, 2003, vol. 55, no. 8, pp. 1273-1303. 
with a promise that new elections will be organized soon. Opposition rejected the offer, Paroubek still hoped he would receive his chance in the second round (see above), yet Klaus opted for Topolánek again and his second attempt lead to a successful outcome thanks to the two cross runners.

Disputes within the ODS and the smallest coalition party (Greens) caused the premature end of this government in 2009, and again a caretaker government consisted of minor politicians was installed with the purposed to lead the country to early elections. But as these were annulled by the Constitutional Court, this government remained in office until the regular date of election in June 2010. Once more a close result was expected, but while ČSSD won, amazingly the right-wing parties received 118 mandates and for the first time in the history of the Czech Republic were able to form government without difficulties. ${ }^{45}$

\subsection{Closing phase: Chamber of deputies steps in}

Once the role of President is over, the responsibility turns to the hands of deputies in the Chamber. The chairman sets the date of the investiture vote, usually it is the only agenda for the day. The question arises what exactly one means by the "confidence". Chamber of Deputies only proclaims in its resolution that "government gained confidence". As the government has hardly done anything yet, the deputies are not able to assess its real activities such as in the case of noconfidence vote. ${ }^{46} \mathrm{But}$, in a political system based on the competition of political parties, confidence is best expressed as the support for a political programme representing the compromise agreed among the coalition parties. ${ }^{47}$

Even before the government is appointed, its member parties often conclude a coalition agreement which is endorsed by the parties' structure. The coalition agreement however usually dedicates a large part of space to internal working mechanisms of the coalition and allocation of seats in the executive rather than programmatic aims. The intentions of future government are thus described in detail in its programme. In Czechoslovakia government's programme was an obligatory part of the investiture vote..$^{48}$ Contemporary Constitution dropped the requirement, still all governments prepared the programme and it has already become a constitutional custom. The 30 days window between the appointment and vote of investiture might be viewed as time for preparation of the programme. It is not easy to make any generalizations about these texts. Caretaker governments tend to issue the shortest documents (see table in annex),

45 Since July 2010, this government has been on the verge of internal breakout several times, but that is for another story.

46 If the government has similar composition as the previous one, this objection does not hold.

47 Similarly MLSNA, Petr. Komentár k čl. 68 [Commentary to Art. 68]. IN: KLÍMA, Karel (ed). Komentár k Ústavě a Listině: 1. dil [Commentary to the Constitution and the Charter: Part I.]. Plzeň: Aleš Čeněk, 2009, p. 530.

48 According to the 1960 Constitution, the vote of investiture was taken by a vote on government's programme. 
but (political) the government of Topolánek I. and Paroubek were also supposed to rule only for about a year and still they submitted above average texts. One would expect that the fewer parties in government, the shorter the text as compromises theoretically tend to prolong any agreement, but the correlation is not there. It is clear the texts are not mere proclamations and often contained very detailed prescription of planned activities, in this they served more as a binding contracts to the coalition (and supporting deputies) rather than tools aiming to persuade the opposition.

During Czechoslovak times, the programme was first read by the PM during the investiture vote. In 1996 the coalition wished to continue the tradition and tried to reject the demand of CSSD to provide it in advance, but had to yield and submitted it to all parties several hours before the vote. On the other hand, PM Zeman in 1998 provided the programme to the deputies in advance and said it would be useless to read it. His successor Špidla also had the text printed out, but undaunted proceeded to read the whole 50 pages to an almost empty chamber. Subsequent governments did not establish any pattern, again some of them even tried to keep it secret until the vote. This attitude could be explained by the fact that if the government counts on tacit support of any party, revealing the programme might lead to another round of concession requests, while the presentation during the vote leave no time for manoeuvre. But if the (tacit or direct) support is really needed, the programme might reflect the agreements with objects outside the government, case in point is the Opposition Agreement. In 2006 Topolánek included parts of the written agreement he made with the cross runners, ČSSD supported the caretaker government in 1998 only after the Chamber itself adopted a resolution that the Social Democrats conditions on new government will be met.

The presentation of programme (if it is read) is followed by debate. Although it could hardly change the result of the vote, it is traditionally a high point of the Chamber's life, also because it is transmitted live on TV. Usually dozens of deputies are rotating behind the lectern and the debate continues for many hours (see table in annex). Again there is little that could be deduced from the process. Data confirms that generally the length of debates has slightly decreased over time and the more controversial the formation of the government was, the longer the debate. In practice the whole endeavour is debated only by name, because the majority of deputies prefer to read their prepared speeches, the bulk of time is taken by the parties leaders. Obviously opposition is more active, but coalition is involved as well, the exception being the last government of Nečas, which left the opposition to speak with no interference from coalition deputies.

After the conclusion of the debate a vote is taken. In light of the slight majorities in the Chamber in the past, each deputy was important. That caused numerous problems as naturally not all deputies were healthy enough to participate. Traditionally this situation is solved (not only during the vote of investiture, but any vote) by the so-called pairing, an informal process when excused deputy 
of the opposition is counterbalanced by a deputy from the ruling parties (or vice versa) who intentionally does not vote. This system is conventional for both sides, as it is impossible to maintain full participation throughout the whole election period. But sometimes the tempers during the investiture vote were so bad that the opposition rejected pairing, arguing that the expected tragic consequences of the new government prevailed over moral issues. Therefore, the viewers had to experience disturbing pictures of seriously ill deputies taken from the hospital with great risks just to vote. Voting is taken by names, when each deputy has to stand up and clearly express himself. ${ }^{49}$ "For proposal" means support for government, "against proposal" opposition, everything else is taken as abstention. Amusing situations happened, for example in 2006 social democratic deputy answered "I am against proposal", which had to qualify as abstention. ${ }^{50}$ The votes are counted by the registrars, a brief break is taken and after that the (already well-known) results are announced. If confidence is proclaimed, new government gained legitimacy and might fully immerse in its duties.

\section{Proposals for reform}

The rules dealing with the process of government formation has remained the same since the adoption of the Constitution. But there were several proposals how to reform the mechanisms. Few concentrated on the streamlining of steps, namely by introducing fixed deadlines. Each time instability in the Chamber of Deputies occurred, arguments for positive impact of constructive veto of no confidence were raised. But these ideas were only tentative and never made it to the legislative proposals, although the constructive veto has become part of the latest government programme. ${ }^{51}$

The only proposal discussed in the Parliament was the one tabled in 1999 by ODS and ČSSD during the times of the Opposition Agreement. ${ }^{52}$ It planned to amend numerous parts of the Constitution, including the process of government formation. The core of the adaptations in this area concerned the initial phase, namely the role of the President. According to the new rules, after the elections he had to ask the representative of the strongest party to propose him the composition of a government within a 30 day limit. If his request was not accepted or the appointed government did not win the vote of investiture, the representative of the second party with most mandates had its turn. An unsuccessful result would move the baton to the chairman of the Chamber of Deputies, who had seven days to choose a citizen, who would be asked by the President to compose

49 See Art. 85 para 1 RP. The name of the starting deputy is taken by draw.

50 It had no impact on the result, as Topolánek had two crossrunners. The "confused" deputy later also became crossrunner, so maybe his mistake was intentional.

51 Programové prohlášení Vlády České republiky [Programme of Government of the Czech Republic], 4th August 2010, p. 21. Available from http://www.vlada.cz/assets/media-centrum/dulezite-dokumenty/Programove_prohlaseni_vlady.pdf (visited on 14th July 2011).

52 Sněmovní tisk [Chamber of Deputies Print] 359. 17th September 1999. Available from http://www.psp.cz/sqw/historie.sqw?o=3\&T=359 (visited on 14th July 2011]. 
a government in ten days. In case the vote of investiture failed for the third time, the Chamber had to be dissolved by the President. Similar rules applied when government resigned or was voted out between elections, only the limits for the selection of governments were reduced to ten days. In all cases the appointed government had to undergo the vote of investiture in 15 days.

Clearly the amendment aimed to reduce the scope of President's discretion and made him basically just a notary initiating prescribed parts of the script. Secondly, the position of informateur was constitutionalized, he or she would have the option to choose the PM and ministers, because the whole team would be appointed together. Thirdly, new deadlines were introduced and the existing ones were shortened.

Proposing parties defended the changes by claiming that the amendment "only introduces mechanisms commonly self-evident in parliamentary democracies", but without any concrete references.$^{53}$ Realistically it was obvious they wish to limit the role of President Havel, who strongly criticized the Opposition Agreement and personally intervened into the solution of the government's crisis in 1997-1998. One of the proposal's authors openly admitted that there was need to reduce the space for the "subjective attitude of the President". ${ }^{4}$ In practice, both CSSD and ODS expected one of them would always be the strongest party in the foreseeable future, therefore the rules could have guaranteed them first formation turns for a long time..$^{55}$

The proposal was successfully adopted by the Chamber of Deputies, but it was unable to obtain the necessary constitutional majority in the Senate, where ČSSD and ODS did not command enough votes. Senators also condemned the content of the changes, arguing that it is an attempt "to constrain in useless detail situations which are ... easier to solve by heeding to relatively free manoeuvring space of each constitutional institution." ${ }^{\text {"5 }}$ Numerous experts criticized the amendment as well, disproving it with historic, logical and comparative arguments. ${ }^{57}$ With a chance of hindsight, I could say that if the proposal is applied on the real situations in the last ten years, it would have brought similar results in

53 Explanatory Memorandum available on the address in previous footnote.

54 LANGER, Ivan. Co přináší novela Ústavy České republiky a proč? [What Brings the Amendment of the Constitution and Why?]. IN: DANČÁK, Břetislav, ŠIMíČEK, Vojtěch (eds). Aktuálnost změn Ústavy ČR [Relevance of Czech Constitutional Amendments]. Brno: Masarykova univerzita, 1999, p. 112.

55 See MOLEK 2010, pp. 834-835.

56 Usnesení č. 13 Komise Senátu pro Ústavu České republiky [Resolution no. 13 of the Senate Commission for the Constitution of the Czech Republic]. 31st May 2000. Available from http://www.senat.cz/xqw/xervlet/pssenat/htmlhled?action=doc\&value $=15998$ (visited on 14th July 2011].

57 In detail for example ŠIMÍČEK, Vojtěch. Komentář k návrhu na vydání ústavního zákona, kterým se mění Ústava ČR - Sněmovní tisk 359 [Commentary to the Proposal to Issue Constitutional Act Amending the Constitution of the Czech Republic - Chamber of Deputies Print 359]. IN: DANČÁK and ŠIMÍČEK (eds) 1999, pp. 125-128. 
the majority of cases, but rather damaging effects in others, while any possible positive impact would be hard to find.

\section{Conclusion and comparative snapshot}

Positively formulated investiture rules are nowadays deeply entrenched in the Czech constitutional culture and apart from few eccentric experts (see above), nobody contradicts them. Generally speaking, three main advantages to negative rules are mentioned in relation to the procedure. Firstly there is a question of legitimacy. The Constitution says that all power stems from the people (Art. 2 para 1 Const.). The President is elected indirectly by the Parliament. Had negative rules sufficed and the government would base its position only from the head of state, the link to the people would be simply too weak. Secondly, positive rules should contribute to effective administration of the state. The vote of investiture confirms the government is able to command enough deputies in the Chamber in order to force it will and ideally to fulfil the promises the coalition parties gave to the (majority) of the voters. Finally, it balances the power relations within the executive, that is between the government and the President. If the latter knows the PM appointed by him must have support in the Chamber, he is bound to choose wisely and should not pursue his own political agenda.

It is difficult to assess how the theoretical assumptions are converted into practice. The legitimacy link could hardly be questioned, as in Czech politics the Chamber maintains a strong position vis a vis other institutions, to base the power only on the head of state would hardly be acceptable. The Effectiveness of the government provides however a much bleaker picture. The miniscule majorities the governments usually had meant that while they were able to scrap enough votes for the investiture, this did not necessarily happen for the regular votes on acts or other issues. It is difficult to lead a country if each coalition's deputy knows he or she has the decisive vote and blackmails the government accordingly. The role of the President was discussed above in detail, while there were occasions where both Havel and Klaus interpreted their rights somewhat extensively or even praeter constitutionem, all in all the decisions they took could hardly be labeled undemocratic or even unfair, despite all the critique. In this sense the threat of investiture indeed has a constraining impact on the President.

If we use the typology proposed by Kaare Strøm et al, ${ }^{58}$ the Czech Republic is an example of a state in which the electoral results influence the government formation much more than the institutional constraints. Indeed the number of constraints are very limited and politicians are able (or must) to invent innovative ways out of the looming deadlock. Reconciliation between the biggest foes, sudden change of positions, violations of "unbreakable" promises, drafting of opposing deputies by whatever means, that all was experienced with incessant lamenting of commentators on ever decreasing political morality. On the other

58 STRØM, Kaare et al. Constraints on Cabinet Formation in Parliamentary Democracies. American Journal of Political Science, 1994, vol. 38, no. 2, pp. 303-335. 
hand, maybe these instruments, despising as they might be, have contributed at least to the illusion externally that the Czech Republic has political stability.

As was explained in the introduction, while I deliberately omitted comparative insights in the article, at least a very brief sketch is limited to this closing paragraph. Each reader interested in comparison of various data with other CEE countries is kindly referred to articles by Zeynep Somer-Topcu together with Laron Williams ${ }^{59}$ and by Courtenay Conrad with Sona Golder, ${ }^{60}$ the length of government formation in Western European states is provided by Daniel Diermeier and Peter van Roozendaal. ${ }^{61}$ Despite all the methodological difficulties with measurements and the fact that the averages could change very quickly with the limited number of cases in new democracies, ${ }^{62}$ it is quite obvious that the postelection government formation process has been much slower than in other both Western and CEE countries. We can thus confirm the expected impact of positive investiture rules, exacerbated by often very close results of elections. In the case of Czech governments' stability the positive rules have helped as well. While at first sight the duration of Czech governments is about average compared to CEE and shorter to Western Europe, ${ }^{63}$ given the circumstances it is quite an unexpected result, and I even do not take into account that between 2002 and 2006 there was actually only one government, because everything remained the same but the PMs, who were replaced for intraparty reasons. On the other hand, not all theoretical hypotheses are confirmed, for example the number of minority governments in the Czech Republic has been relatively high for positive rules.

59 SOMER-TAPCU, Zeynep, WILLIAMS, Laron. Survival of the Fittest? Cabinet Duration in Post-Communist Europe. Comparative Politics, 2008, vol. 40, no. 3, pp. 313-329.

60 CONRAD, Courtenay, GOLDER, Sona. Measuring government duration and stability in Central Eastern European Democracies. European Journal of Political Research, 2010, vol. 49, no. 1, pp. 119-150.

61 DIERMEIER, Daniel, ROOZENDAAL, Peter van. The Duration of Cabinet Formation Processes in Western Multi-Party Democracies. British Journal of Political Science, 1998, vol. 28 , no. 4, p. 609-626.

62 In 2004, article by Müller-Rommel set the average duration of government in the Czech Republic to 869 days, which was second longest in CEE (MÜLLER-ROMMEL, Ferdinand et al. Party government in Central Eastern European democracies: A data collection (1990-2003). European Journal of Political Research, 2004, vol. 43, no. 6, p. 876), six years later the number plummeted to 569 days and resulting $5^{\text {th }}$ position (CONRAD and GOLDER 2010, p. 127.

63 For Western Europe (although already quite old) data see WARWICK, Paul. Government survival in parliamentary democracies. Cambridge: Cambridge University Press, 1994, p. 6.

\footnotetext{
(C) Palacký University Olomouc, Czech Republic, 2011. ISSN 1213-8770 (print), ISSN: 2464-6601 (online).
} 


\begin{tabular}{|c|c|c|c|c|c|c|c|c|c|c|c|c|}
\hline 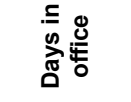 & 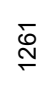 & 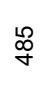 & $\stackrel{8}{\circ}$ & 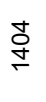 & జ్ & $\underset{\sim}{-}$ & ஜூ & $\infty$ & 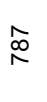 & 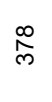 & $\Sigma$ & 周 \\
\hline 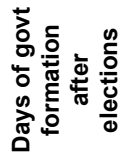 & $\stackrel{\sim}{N}$ & L & & $\stackrel{\infty}{\infty}$ & గొ & & & $\stackrel{\text { N}}{\mathrm{V}}$ & & & $\bar{r}$ & I \\
\hline 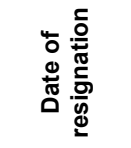 & 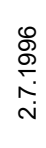 & 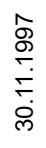 & 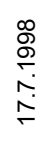 & $\begin{array}{l}\stackrel{N}{o} \\
\text { N̦} \\
\stackrel{N}{\sim}\end{array}$ & $\begin{array}{l}\stackrel{+}{8} \\
\stackrel{N}{~} \\
\stackrel{-}{r}\end{array}$ & 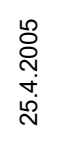 & $\begin{array}{l}\mathscr{0} \\
\stackrel{0}{1} \\
\infty \\
0 \\
0\end{array}$ & 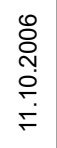 & 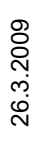 & $\begin{array}{l}\stackrel{0}{\circ} \\
\text { ஸู } \\
0 \\
\stackrel{\sim}{N}\end{array}$ & $\Sigma$ & \\
\hline 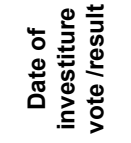 & 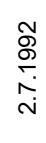 & 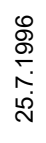 & $\begin{array}{l}\infty \\
\stackrel{\circ}{\circ} \\
\stackrel{亠}{-} \\
\stackrel{\infty}{\sim}\end{array}$ & $\begin{array}{l}\infty \\
\stackrel{\infty}{\circ} \\
\infty \\
\infty \\
\infty \\
\infty\end{array}$ & 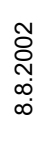 & 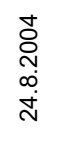 & 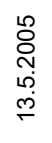 & 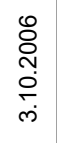 & 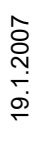 & $\begin{array}{l}\stackrel{8}{0} \\
\text { N̦ } \\
\dot{0}\end{array}$ & $\begin{array}{l}\stackrel{0}{\circ} \\
\text { ஸे } \\
\infty \\
0\end{array}$ & \\
\hline 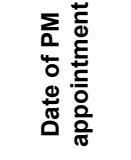 & 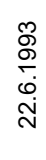 & 穴 & 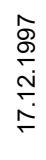 & 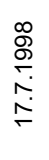 & $\begin{array}{l}\text { Oे } \\
\stackrel{N}{N} \\
\stackrel{N}{N}\end{array}$ & \begin{tabular}{l}
\multirow{O}{0}{} \\
N̦ \\
ì
\end{tabular} & 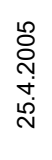 & $\begin{array}{l}0 \\
\varnothing \\
N \\
\infty \\
0 \\
0\end{array}$ & $\begin{array}{l}\mathscr{8} \\
\stackrel{\circ}{+} \\
\stackrel{\infty}{\leftarrow}\end{array}$ & 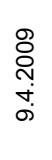 & $\begin{array}{l}\circ \\
\stackrel{\circ}{0} \\
0 \\
\infty \\
\stackrel{0}{N}\end{array}$ & \\
\hline 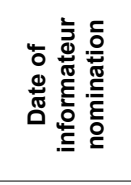 & & & 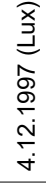 & & & 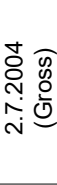 & & & & & 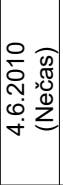 & \\
\hline 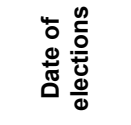 & $\begin{array}{l}\text { ু } \\
\frac{\Omega}{-} \\
\dot{0}\end{array}$ & $\frac{\mathscr{6}}{\stackrel{\circ}{\circ}}$ & $\Sigma$ & $\begin{array}{l}\stackrel{\infty}{\circ} \\
\stackrel{\circ}{\leftarrow} \\
\stackrel{\leftrightarrow}{\circ}\end{array}$ & 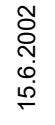 & $\mathbb{z}$ & $\Sigma$ & 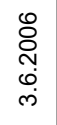 & $\Sigma$ & $\mathbb{z}$ & 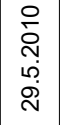 & \\
\hline 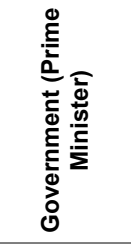 & 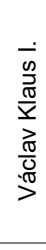 & 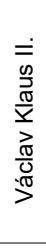 & 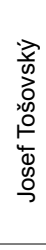 & 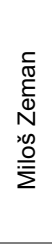 & 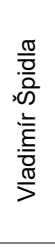 & 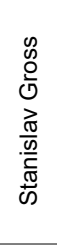 & 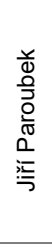 & 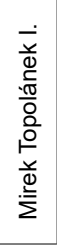 & 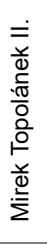 & 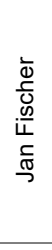 & 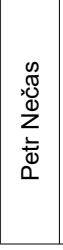 & $\begin{array}{l}\frac{0}{0} \\
\frac{\pi}{0} \\
\frac{1}{\alpha}\end{array}$ \\
\hline
\end{tabular}

Table continues on the next page.

(c) Palacký University Olomouc, Czech Republic, 2011. ISSN 1213-8770 (print), ISSN: 2464-6601 (online). 
ICLR, 2011, Vol. 11, No. 2.

\begin{tabular}{|c|c|c|c|c|c|c|c|c|c|c|c|c|}
\hline 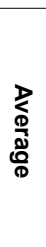 & 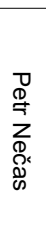 & 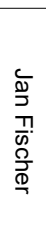 & 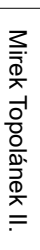 & 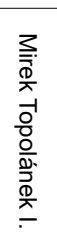 & $\begin{array}{l}\text { ఏ } \\
\overline{0} \\
\bar{D} \\
\overline{0} \\
\frac{0}{0} \\
\frac{\Phi}{\lambda}\end{array}$ & 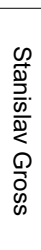 & 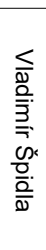 & 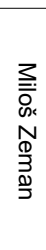 & 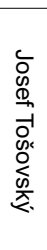 & 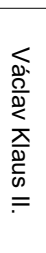 & 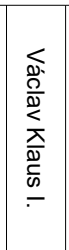 & 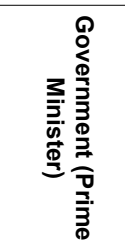 \\
\hline & $\overrightarrow{\vec{\infty}}$ & जु & $\overrightarrow{8}$ & পூ & 오 & $\overrightarrow{\mathrm{o}}$ & $\vec{\circ}$ & $\vec{\omega}$ & $\vec{\omega}$ & 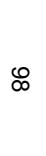 & $\overrightarrow{8}$ & 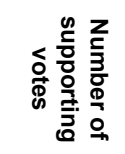 \\
\hline & $\stackrel{\infty}{N}$ & $\rightarrow$ & $\stackrel{\varphi}{v}$ & $\mathscr{8}$ & $\varnothing$ & 8 & $œ$ & $\tilde{\omega}_{0}$ & $\stackrel{v}{a}$ & o & $\stackrel{\varnothing}{\perp}$ & 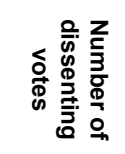 \\
\hline$\oiint$ & ज्ञ & 孞 & $\stackrel{心}{\Perp}$ & $\underset{\omega}{\tilde{\omega}}$ & $\vec{E}$ & $\stackrel{\bullet}{8}$ & $\begin{array}{l}\mathcal{M} \\
\stackrel{\infty}{\perp}\end{array}$ & $\stackrel{\sigma}{\vec{N}}$ & $\stackrel{c}{\vec{V}}$ & $\stackrel{\infty}{0}$ & गु & 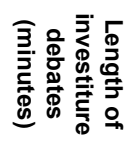 \\
\hline 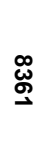 & $\begin{array}{l}\overrightarrow{\vec{\omega}} \\
\vec{\omega}\end{array}$ & $\underset{ \pm}{N}$ & 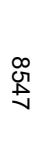 & 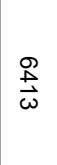 & $\begin{array}{l}\overrightarrow{\vec{E}} \\
\overrightarrow{\mathrm{E}}\end{array}$ & 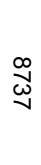 & $\begin{array}{l}\vec{\omega} \\
\tilde{O}_{0} \\
\end{array}$ & $\underset{\overrightarrow{\vec{\omega}}}{\overrightarrow{\vec{V}}}$ & $\underset{N}{N}$ & $\underset{N}{N}$ & హี & 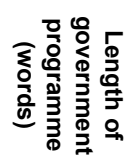 \\
\hline & & 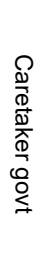 & & 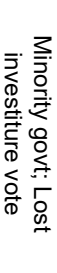 & & & & 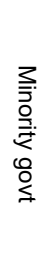 & 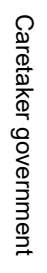 & 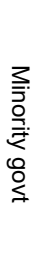 & 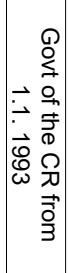 & 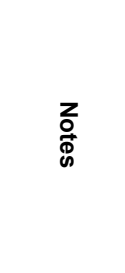 \\
\hline
\end{tabular}

